\title{
Wybrane koncepcje filozoficzne a działania medyczne dla poprawy jakości życia i urzeczywistniania rozwoju
}

\section{Wprowadzenie}

Szeroki zakres przedmiotowy podjętych rozważań uzasadniają dwie przesłanki:

1. K. E. Boulding wyraża pogląd, że ostateczne rozwiązanie każdego problemu ekonomicznego ( także dotyczącego rozwoju S. L.) znajduje się w jakiejś innej dziedzinie ${ }^{1}$. Z kolei N. Wiener, twórca podstaw cybernetyki uważał, postęp w nauce znajduje się na styku dyscyplin. Stwierdzenia te uzasadniają, ze zakres przedmiotowy niniejszych rozważań obejmuje wiele dziedzin nauki: od medycyny przez etykę i filozofie do technologii i ekonomii i w tym wymiarze autor niniejszego artykułu podejmuje próbę oceny wyznaczenia drogi - w obszarze medycyny dla skuteczności poprawy jakości życia i urzeczywistniania rozwoju.

2. Panuje też opinia, że jeszcze żaden z filozofów nie poniósł odpowiedzialności za skutki wywołane w sferze realnej w wyniku głoszonych przez niego poglądów. Przedmiotem analizy jest koncepcja F. Nietzschego, o którym pisze się, że stworzył propozycję terapii w postaci nowego świata intelektualnego ${ }^{2}$ oraz pozostająca do tej koncepcji w określonej relacji koncepcja J. Bańki.

Zgadzając się z faktem, że zarówno osoba Fryderyka Nietzschego jak i jego twórczość stały się wyzwaniem dla potomnych, należy zastanowić się, jakie z idei autora wynikają wskazania i konsekwencje dla poprawy jakości życia i godności człowieka urzeczywistnianej w procesie rozwoju? Podobne pytanie należy zadać w stosunku do eutyfroniki (eu - dobry, thymos - uczuciowość, phronos - rozum) Józefa Bańki.

Cyt. za D. Morrisonem, Rozwój gospodarczy. Strategia dla samorząów gospodarczych, Agencja Rozwoju Lokalnego (b.r.w.).

2 P. Kunzmann, F. P. Burhard, F. Wiedmann, Atlas filozofii, Prószyński i i S-ka, Warszawa 1999, s. 179. 
Jakość życia - za Barbarą Piontek (2006) - definiuję jako spełnienie obiektywnych norm aksjologicznych, przy jednoczesnym zaspokajaniu subiektywnych oczekiwań jednostki, w stopniu co najmniej zadowalający (B. Piontek, 2006) ${ }^{3}$.

Kategoria godność człowieka w szerokim rozumieniu oznacza, że człowiek jest wartością podstawową. W obszarze natury godność człowieka determinowana jest faktem, że człowiek jest osobą, a jako osoba jest indywidualnością pod względem anatomicznym, czynnościowym i umysłowym. Jest niepowtarzalny w swojej jednorazowości (Letkiewicz 2009)4.

A kategorię rozwój - jako proces przeobrażeń, zmian, przechodzenia do stanów lub form bardziej złożonych lub pod pewnym względem doskonalszych, podporządkowany godności osoby ludzkiej i spełniający kryteria artykułowane przez depozyt niezrelatywizowanych wartości (B. Piontek, 2006) ${ }^{5}$.

Kategoria rozwój jest kategorią podstawową i jako taka powinna spełniać dwa założenia:

- posiadać umocowania aksjologicznie, co oznacza, że aksjomaty i prawo naturalne pełnia w tej kategorii funkcje kryterialne i każdą koncepcję rozwoju weryfikują z punktu widzenia sensu $i$ celu ludzkiego istnienia $i$ działania (F. Piontek 2007).

- definicja tej kategorii powinna być tak sformułowana, aby mogły z niej korzystać wszystkie dyscypliny naukowe, w tym także medycyna. To może być zapewnione poprzez umocowanie aksjologiczne tej kategorii (F. Piontek, 2006) ${ }^{6}$. Z kategorią rozwój ściśle wiąże się kategoria rozwój zrównoważony i trwały. W literaturze nie jest ona jednoznacznie definiowana. Definicje między innymi zinwentaryzowała B. Piontek (B. Piontek, 2002) ${ }^{7}$, a F. Piontek wykazał, że rozwój zrównoważony posiada własną naturę, własną oryginalną jakość. Jest koncepcją naturalną, a nie kolejną propozycją intelektualną ( F. Piontek 2004). W tym ujęciu definicja rozwoju zrównoważonego i trwałego jest następująca: jest to trwała poprawa jakości życia wspólczesnych i przyszłych pokoleń poprzez kształtowanie właściwych proporcji miedzy trzema rodzajami kapitału: ekonomicznym (E), ludzkim (L) i przyrodniczym (P) (F. Piontek, 2006) .

3 B. Piontek, Współczesne uwarunkowania rozwoju społeczno - gospodarczego, Wydawnictwo ATH, Bielsko-Biała 2006, p. 125 - 126.

4 S. Letkiewicz, Kryterium wyznaczania granic prawnych i etycznych $w$ badaniach medycznych $w$ aspekcie urzeczywistniania konstytucyjnej zasady zrównoważonego rozwoju, Problemy Ekorozwoju, vol. 4 no 1, 2009, s. 49-60.

5 B. Piontek, , Współczesne uwarunkowania rozwoju społeczno - gospodarczego, op. cit., s....

6 F. Piontek, 2006. Spór wokół kategorii rozwój i rozwój zrównoważony - jego konsekwencje dla teorii i praktyki (w:) Problemy Ekologii, nr 6, 2006, s. 283-291.

7 B. Piontek, Koncepcje rozwoju zrównoważonego i trwałego Polski, Wyd. naukowe PWN, Warszawa 2002, s.15-26.

8 F. Piontek, Spór wokól, op. cit. 
Wybrane koncepcje filozoficzne a działania medyczne dla poprawy jakości życia...

I właśnie ta definicja znalazła pełną akceptację na szczycie Zrównoważonego Rozwoju w Johannesburgu (2002).

Jakość życia będąca składową treści definicji rozwój zrównoważony i trwały pełni w niej funkcje kryterialne i gwarantuje, że również definicja rozwoju zrównoważonego jest umocowana aksjologicznie. Dla porównania - za E. Leks-Bujak - prezentujemy definicję rozwoju zrównoważonego zawartą w Raporcie Komisji ONZ ds. Środowiska i Rozwoju Our Common Future z 1987, która nie legitymuje się umocowaniem aksjologicznym: zrównoważony rozwój jest tu definiowany „jako proces mający na celu zaspokojenie aspiracji rozwojowych obecnego pokolenia z zachowaniem możliwości zaspokojenia tych samych aspiracji przez przyszłe pokolenia (E. Leks-Bujak, 2009)9 . A pytaniem jest, co to są i jakie mogą być aspiracje oraz jaka może być skala możliwości ich zaspokojenia przy ograniczonych zasobach? Czy możliwości zawsze staja się bytem (realnym rozwiązaniem)? Z faktu, że obydwie kategorie: (rozwój oraz rozwój zrównoważony i trwały- zdefiniowany jak wyżej w tekście) posiadają umocowanie aksjologiczne wynika, że kategorie rozwój i rozwój zrównoważony są synonimiczne (F. Piontek 2006) ${ }^{10}$.

Nadto kategoria rozwój zrównoważony może występować jako zasada, która oznacza, że jeden podmiot (układ) nie może rozwijać się kosztem pozostałych (F. Piontek 2006) ${ }^{11}$.

Na takie rozróżnienie w kategorii rozwój zrównoważony i trwały zwrócił właśnie uwagę F. Piontek, a ma ona swoje uzasadnienie w Konstytucji RP: art. 5 i 20 - ten ostatni określa koncepcję rozwoju - społeczna gospodarka rynkowa; (F. Piontek 2006) ${ }^{12}$.

Treść definicji cytowanych kategorii: jakość życia, godność człowieka i rozwój pozwala stwierdzić, że zarówno temat niniejszej pracy jak i idee F. Nietzschego, a także J. Bańki wpisują się w zakres przedmiotowy tych kategorii.

Celem moich rozważań jest odpowiedź na pytanie: czy idee wymienionych autorów wpisują się w zakres przedmiotowy tych kategorii w sposób bezpośredni czy - jedynie - pośredni i czy wytrzymują one próbę budowania cywilizacji technologicznej? Czy są one w stanie skutecznie wyznaczać drogę dla rozwoju? Czy medycyna korzystając $\mathrm{z}$ tych idei potrafi skutecznie zapewnić trwałą poprawę jakości życia.

Dla niniejszych rozważań formułuję hipotezę, że idee F. Nietzschego i J. Bańki w sposób bezpośredni wpisują się w etykę lekarską, $w$ deontologię i w etykę w ogóle. A jako takie moga przyczyniać się - w sposób pośredni - do trwałej poprawy jakości życia i urzeczywistniania rozwoju, a tym samym rozwoju zrównoważonego

9 E. LeKs-BujaK, Stosunek człowieka do zwierząt a koncepcja zrównoważonego rozwoju (w:) Problemy ekorozwoju nr 2, 2009, s. 84-85.

10 Ibidem.

11 Ibidem.

12 Ibidem. 
i trwałego. Jednak ocena skuteczności ich oddziaływania nie jest oczywista, ale wykracza poza niniejsze rozważania, ponieważ zależy ona od wielu uwarunkowań zewnętrznych (także od stosowanych procedur), których ocena wpływu jest bardzo złożona i wymaga oddzielnych analiz.

\section{F. Nietzsche i J. Bańka wobec źródeł zachowań moralnych człowieka}

Fenomen renesansu filozofii F. Nietzschego - jednych cieszy, drugich przeraża. Dotyczy to zarówno opinii wypowiadanych zaraz po śmierci Nietzschego, jak i ocen współczesnych komentatorów i znawców jego twórczości. „Reakcją uczonych, którzy uznali poglądy Nietzschego za afront, były rezerwa i żelazne milczenie” (Frenzel, 1994) ${ }^{13}$. Jurgen Habermas twierdził, że „Nietzsche nie ma już w sobie nic interesującego" (Habermas, 1970) ${ }^{14}$. Z kolei Artur Coleman Danto wyraził opinię na temat twórczości Nietzschego: „....nigdy nie znajduję u niego rzeczy, w oparciu o które można by żyć" (Danto, 2000) ${ }^{15}$. Z drugiej jednak strony, Krzysztof Wieczorek wydaje pracę na temat myśli Nietzschego pod znamiennym tytułem, „Wieczne powroty Fryderyka Nietzschego"(Wieczorek, 1998) ${ }^{16}$. R. F. Krumel, zauważa, że „nie sposób prawie znaleźć artykułu, w którym nie napotkałoby się nazwiska Nietzschego" (Krumel, 1974-1983) ${ }^{17}$. Już w 1900 roku ukazał się w Kijowie pierwszy książkowy polski przekład tekstu Nietzschego (Weiss, 1961 ${ }^{18}$. Stanisław Przybyszewski porównywał geniusz Nietzschego do geniuszu Fryderyka Chopina (Baran, 1997) ${ }^{19}$. Ewa Bieńkowska zestawiła ze sobą biografię Nietzschego i Cypriana Kamila Norwida (Bieńkowska, 1975) ${ }^{20}$. Lew Szestow szukał podobieństw myśli między Nietzsche a Fiodorem Dostojewskim (Szestow, 1987) ${ }^{21}$. Natomiast Tadeusz Sławek odnajduje bliskość myśli Nietzschego i Wiliama Blake’a (Sławek, 1994) ${ }^{22}$, a F. Piontek przedstawił rolę i znaczenie nihilizmu F. Nietzschego dla teorii rozwoju oraz dla kształtowania ładu struktural-

13 I. FrenZel, Nietzsche, przekł. J. Dziubiński, Wrocław, 1994, s. 53.

14 J. Habermas, Nietzsche: Erkenntnistheorische Schiften [w:] Arbeit, Erkenntnis, Fortschrift. Aufsatze 1954-1970, 1970, s. 356.

15 A. Danto, A Conversation with Arthur Danto. Conference. "A Journal of Philosophy and Theory”. Cytat za: Z. KuźmierCZA: Friedrich Nietzsche jako odnowiciel umysłowości pierwotnej. Analiza w kontekście fenomenologii Gerardusa van der Leeuwa, Kraków 2000, s. 492.

16 K. WieczoreK, Wieczne powroty Fryderyka Nietzschego. Katowice 1998.

17 R. F. KrumeL, Nietzsche und der deutsche Geist, Berlin 1974-1983, I, s. 108.

18 T. WeIss, Fryderyk Nietzsche w piśmiennictwem polskim lat 1890-1914, Kraków 1961.

19 B. Baran, Postnietzsche, Kraków 1997, s. 109.

20 E. Bieńkowska, Dwie twarze losu. Nietzsche-Norwid, Warszawa 1975.

21 L. Szestow, Dostojewski i Nietzsche. Filozofia tragedii, przekł. I. C. Wodziński, Warszawa 1987.

22 T. SŁAWEK, Człowiek radosny. Blake-Nietzsche. Katowice 1994. 
Wybrane koncepcje filozoficzne a działania medyczne dla poprawy jakości życia...

nego i ładu w nauce (F. Piontek 2007, 2009) ${ }^{23}$. Wobec tak różnorodnych opinii można - za Lucem Ferrym i Alainem Renautem - zapytać, „dlaczego nie jesteśmy nietzscheanistami?” (Ferry, Renaut, 1997) ${ }^{24}$. A może - wręcz przeciwnie dlaczego nimi nadal jesteśmy Może dla tego, że bez trudu daje się odnaleźć idee Nietzschego w jednej z oryginalniejszych współczesnych propozycji etycznych, a mianowicie w etyce prostomyślności Józefa Bańki.

Wydaje się, że twórczość Nietzschego jest spełnieniem jego obietnic, kiedy mawiał o sobie, że nie jest filozofem, lecz „dynamitem”. „Przysięgam - pisał w liście do Paula Deussena - że mam dość siły, by odmienić rachubę czasu. Wszystko, co dziś stoi, upadnie, jestem raczej dynamitem niż człowiekiem” (Nietzsche-Listy, 1994) ${ }^{25}$. Dynamitem, który, jeśli nie będzie panaceum na kryzys kultury europejskiej, to stanie się tym, który doprowadzi do jej ostatecznej „dekadencji ras” (Nietzsche-Pisma pozostałe,1994) ${ }^{26}$. Wydaje się, że w podobne podejście proponuje J. Bańka w swojej eutyfronice, w ramach której przedstawia diagnozę i środki terapeutyczne „przeciw szokowi przyszłości”.

Hipokryzja, która cechuje Nietzscheańskich „niewolników” stanowi swoistą nić łączącą filozofię autora „Zaratustry” i koncepcję „Łżeczłowieka” J. Bańki $\left(\right.$ Bańka, 1997) ${ }^{27}$. W okresie dekadencji obniża się wola mocy (Nietzsche, 1907) ${ }^{28}$, podobnie jak i w okresie zagrożeń rozwojem cywilizacyjnym następuje przerost "phronos" nad "thymos"czynnika fronetycznego (racjonalnego) nad tymicznym (uczuciowym), co prowadzi do zagubienia „zasady antropicznej”(Bańka, 1986) ${ }^{29}$. W takiej sytuacji - zdaniem autora „Wiedzy radosnej” - „we wszystkim liczą się jedynie stopnie wyższe” (Deleuze, 1993) ${ }^{30}$, albo - jak określił je Bańka - „wartości zimne" (Bańka, 1997) ${ }^{31}$. W mojej opinii obaj autorzy powracają, czy może raczej bronią idei „natywizmu aksjologicznego" jako źródła zachowań moralnych człowieka.

23 F. Piontek, Podstawy teorii rozwoju (w:) Rozwój: godność człowieka - gospodarowanie poszanowanie przyrody. Księga Pamiątkowa Prof. zw. dr hab. Franciszka Piontka, Red. B. Piontek, W. Piontek, PWE, Warszawa 2007, s. 59-91; F. PIONTEK, Aksjomat „Człowiek najwyższa wartościa w świecie przyrody” podstawa ładu strukturalnego i ładu w nauce (w:) Nierówności społeczne a wzrost gospodarczy. Uwarunkowania instytucjonalne. Pod red. M.G. Woźniaka, Zeszyt nr 14, UR, Rzeszów 2009.

24 L. Ferry i A. Renaut (ed.) Why We Are Not Nietzscheans, trans. R. de Loaiza, Chicago.

25 F. Nietzsche, Listy, przekł. B. Baran, Kraków 1994, s. 382.

26 F. Nietzsche, Pisma pozostałe 1876-1889, przekł. B. Baran, Kraków 1994, s. 260.

27 J. BAŃKA, Rap metafizyczny, czyli Odezwa wariata $z$ Opatowa do reszty szaleńców. Ułożył i objaśnieniami w postaci postyll opatrzył J. Bańka. Katowice 1999, s. 166 i in.

28 F. Nietzsche, Antychryst. Przemiany wszystkich wartości. Przedmowa i księga pierwsza: Próba krytyki chrześcijaństwa, przekł. L. Staff, Warszawa 1907, s. 49-50.

29 J. BAŃKA, Antropologia różniczkowa, czyli recentywizm jako źródło etyki prostomyślności [w:] Tenże (red.), Etyka prostomyślności a tradycje kultury, Katowice 1986.

30 G. Deleuze, Nietzsche i filozofia, przekł. B. Banasiak, Warszawa 1993, s. 12 i in.

31 J. BAŃKA, Cywilizacja - obawy i nadzieje. Warszawa 1997, s. 15. 
Proponowana przez J. Bańkę eutyfronika wyrosła z obawy przed zagrożeniami, jakie niesie ze sobą gwałtowny rozwój techniki. Twórca nowych rozwiązań technologicznych stał się w wielu przypadkach ich ofiarą. Pojawił się problem adaptacji człowieka do nowego - stworzonego przez niego - sztucznego środowiska, które miało rozstrzygać problemy, a w istocie postawiło go przed nowymi, niejednokrotnie o wiele trudniejszymi, czy wręcz - w jego opinii - nierozwiązywalnymi. $\mathrm{W}$ wielu przypadkach dotyczy to obszaru medycyny, gdzie stale wdrażane nowe technologie stawiają lekarzy i personel medyczny w sytuacjach do rozwiązywania, do których nie są przygotowani. W dziedzinach medycznych postęp techniczny związany z zastosowaniem nowej aparatury diagnostyczno-terapeutycznej znacznie wyprzedził postęp w dziedzinie humanizacji personelu. Doszło do procesu zawłaszczenia psychiki przez technikę. Nastąpiła swoista dysproporcja między rewolucją techniczną, a ewolucją wartości, polegająca na ich odczytywaniu w nowych uwarunkowaniach. Przed tymi zagrożeniami, ani nie można obronić się powstrzymując, ani chociażby spowolniając rozwój cywilizacyjny, który w coraz większym stopniu podlega i realizuje tendencje unifikacji i globalizacji. Na tego typu zagrożenia reakcją ma być proponowana przez Bańkę eutyfronika, która ma doprowadzić do harmonijnego współistnienia człowieka i środowiska, człowieka i maszyny, co pozwoli mu odnaleźć swoje miejsce i adoptować się w tym sztucznym, technologicznym środowisku. Przede wszystkim eutyfronika stawia sobie za cel obronę godności i życia osobowego człowieka. Problem jest jednak bardziej złożony. Współcześnie kategoria technologie definiowana jest jako procedury postępowania (Ritzer, 1997) ${ }^{32}$ i obejmuje także reguły technologiczne, które umożliwiają zawłaszczanie świadomości (B. Piontek, 2006) ${ }^{33}$, która w świecie obfitości dóbr postrzegana jest jako towar ekonomiczny i deficytowy.

Bańka akcentuje związane z rozwojem techniki zjawisko, a wręcz paradoks „przełatwienia”. Chodzi mianowicie o to, że urządzenia ułatwiają codzienne życie człowieka, a jednocześnie prowadzą do destrukcji jego osobowości, pozbawiają go celu i sensu życia. Życie łatwe staje się pozbawione wartości, spłycone i nudne. Jednocześnie znosząc wysiłek fizyczny owo „przełatwienie” stawia coraz większe wymagania wobec umysłu, a zwłaszcza wobec psychiki, będąc przyczyną stresów i depresji. Z tego powodu eutyfronika musi być nauka interdyscyplinarną, jako swoistą „sumą antropologiczną".

W tej propozycji filozoficzno-etycznej najistotniejsze jest wyróżnienie w człowieku sfery tymicznej (uczuciowej) i sfery fronicznej (racjonalnej), które dla prawidłowego rozwoju człowieka muszą zostać zharmonizowane. Jednak w dobie instytucjonalizacji życia społecznego, nawet jeśli człowiek daje sobie radę $\mathrm{z}$ ada-

32 G. Ritzer, Mcdonalizacja społeczeństwa, Wydawnictwo Muza S. A., Warszawa 1997, s. 177-178.

33 B. Piontek, Współczesne uwarunkowania..., op. cit., 2006, s. 31-36 i 218-241. 
Wybrane koncepcje filozoficzne a działania medyczne dla poprawy jakości życia...

ptacją intelektualną, oswaja się ze sposobem posługiwania się urządzeniami, to w sferze adaptacji emocjonalnej odczuwa on lęk, a często i strach. Bańka podkreśla, że racjonalne sposoby odnajdywania siebie w nowym świecie technicznym i informatycznym podaje, opracowana przez Kotarbińskiego, prakseologia, jak i ergonomia. Jednak zapominają one o tzw. „ciepłych” zaleceniach dotyczących psychiki ludzkiej. Obawa przed niedoborem informacji została zastąpiona przez strach przed jej nadmiarem - „szumem informacyjnym”. Stąd autor proponuje dokonanie humanizacji techniki, którą ma przeprowadzić właśnie eutyfronika, określana w tym kontekście mianem „ciepłej prakseologii”, która zapewnić ma nie tylko skuteczność działania, ale i - co ważniejsze - satysfakcję z niego. Na tej drodze przeciwstawiać się ona będzie dehumanizacji stosunków międzyludzkich oraz relacji między człowiekiem a środowiskiem cywilizacyjnym, czego przejawem jest „metafizyczna lekkość”,a można wręcz powiedzieć lekkomyślność w zachwycie postępem technicznym.

Eutyfronika, rozumiana jako nauka harmonizująca sferę thymos i phronesis w imię dobrze (eu-) pojętej jedności, zapobiega dekompozycji osobowości człowieka, a dzięki temu potrafi oprzeć się „szokowi przyszłości”. Sfery te nie mogą być sobie przeciwstawiane, czy też dążyć do zdominowania siebie wzajemnie, gdyż ma to kolosalne skutki dla zdrowia psychicznego człowieka, dla jakości życia i zapewnienia rozwoju.

$\mathrm{W}$ koncepcji homo euthyphronicus autor wychodzi od przeciwstawienia kategorii thymos i phronesis. Owo przeciwstawienie dotyczy dualizmu człowieka, a także dualizmu kultury technicznej i kultury humanistycznej, którego zniesienia domaga się eutyfronika, a receptę daje etyka prostomyślności. Etyka ta opisuje zachowania człowieka prostomyślnego, który z całą siłą przeciwstawia się „łżeczłowiekowi”. Model takiego człowieka jest źródłem i produktem współczesnego kryzysu nie tylko cywilizacji, ale przede wszystkim kultury. „Łżeczłowiek” za cenę bezpieczeństwa zrezygnował z wolności, a nieufność wobec drugiego człowieka zastąpił bezkrytycznym zaufaniem do urządzeń technicznych. Zajął on postawę niewolniczą, nawet służalczą wobec „nowinek” cywilizacyjnych.

Wyróżniając makro i mikroetykę J. Bańka wychodzi z założenia o elementarnej zgodzie w zakresie wartości prostych, które rozpoznają, i którymi kierują sie ludzie o zdrowych zmysłach. Na tych wartościach, zwanych „ciepłymi” opiera sie solidarność w stosunkach międzyludzkich. Wartości te wyrastają z prawa naturalnego i z niezmiennej ludzkiej natury, czy - jak kto woli - z istoty człowieczeństwa. Zdaniem autora „zimne” normy prawa naturalnego stają się dla człowieka prostomyślnego „ciepłymi” wskazaniami jego zachowania. W dużym skrócie przedstawiam katalogi „zasad zimnych” i „wskazań ciepłych”, które nawiązują do podobnych zestawień wartości w filozofii Tadeusza Kotarbińskiego. J. Bańka na tej podstawie formułuje naczelną normę postępowania, której nieprzestrzeganie prowadzi w konsekwencji do zajęcia postawy „łże człowieka”, a dalej do 
rozbijania wszelkich form więzów międzyludzkich, a zatem do destrukcji i naruszania ładu strukturalnego (w którym proporcje między składowymi kształtowane są zgodnie $\mathrm{z}$ ich naturą), który ma istotne znaczenie dla rozwoju i rozwoju zrównoważonego. Szczególne znaczenie dla etyki prostomyślności mają czynniki wpływające na zdolność człowieka do przetwarzania informacji. Z jednej strony, bowiem istnieje zagrożenie manipulacji przekazem informacji, $\mathrm{z}$ drugiej ich nadmiar i chaos prowadzą do dezinformacji. Czynniki te w odpowiedni sposób modyfikowane i wzmacniane, lub też osłabiane kreują „łże+człowieka”. Mimo krytyki tej postawy Bańka daje szansę dla „łżeczłowieka”, który po przeprowadzeniu przewartościowania wartości może stać się człowiekiem prostomyślnym. Aby postępować godziwie musi on pamiętać o przestrodze, iż niemal każda etyka poddana legalizacji jest - fundamentalnie - nieprostomyślna.

Tylko w jedności „myśli, mowy i uczynku” człowieka ujawnia się prostomyślność, która wdrażana w sferę moralną jako powinność staje się lekarstwem na hipokryzję i samooszukiwanie i stanowi poręczenie moralne. Wynika to z tego, że wyłącznie zasada poręczenia moralnego wypełnia treścią „dyrektywę prostomyślności". Stąd też wartości, poręczenie moralne i prostomyślność tworzą szkielet etyki prostomyślności, która jest w stanie stymulować samodoskonaleniem się człowieka w harmonii z rozwojem cywilizacyjnym.

\section{Podobieństwa i różnice propozycji etycznej F. Nietzschego i J. Bańki i ich praktyczne implikacje}

Celem prowadzonych rozważań jest wskazanie wielu - choć oczywiście nie wszystkich - podobieństw i różnic propozycji etycznej Nietzschego i Bańki, - „człowieka dostojnego” i „człowieka prostomyślnego” - na przykładzie „przewartościowania wartości” i „etyki prostomyślności”. Nietzsche i Bańka zgodnie podkreślają niezależność koncepcji etycznych od religii chrześcijańskiej. Ale czy wspólnym mianownikiem nie jest prawo naturalne, z którego wyrastają wartości proste, a które uznaje religia chrześcijańska? Jednak powody tego izolowania się od teizmu chrześcijańskiego obu twórców były różne.

Nietzsche przedstawiał w stosunku do teizmu chrześcijańskiego oskarżenia o obniżanie wartości i dyskwalifikowanie ludzkiego ciała jako źródła pozytywnych doznań, krytykę naturalnego popędu człowieka, instynktu, namiętności, a wreszcie samego życia. Zarzucał również chrześcijaństwu jako instytucji: samodzielne i pozbawione kontroli korzystanie z umysłu ludzkiego, i umniejszanie wszelkich wartości estetycznych. W „Wiedzy radosnej” Nietzsche stwierdził, że w świetle nowego zdarzenia, jakie miało miejsce, czyli „śmierci Boga”, jak również zaistniałego faktu, że wiara w Boga jest mało wiarygodna (Nietzsche, 1907) ${ }^{34}$, chrześcijaństwo może

\footnotetext{
34 F. Nietzsche, Wiedza radosna („La gaya scienza”), przekł. L. Staff, Warszawa 1907, s. 287-288
} 
Wybrane koncepcje filozoficzne a działania medyczne dla poprawy jakości życia...

wreszcie przejść do lamusa historii, stwarzając przed człowiekiem szansę nieskrępowanego, pełnego rozwoju. Ale czy rozwoju zrównoważonego i trwałego, w którym aksjomaty i prawo naturalne pełnią funkcje kluczowe? Nietzsche głosił tezę, że pojęcie Boga jest wrogie życiu. Aktualny staje się „bezwarunkowy, rzetelny ateizm”, który „zakazuje sobie kłamstwa wiary w Boga”, i dla którego „sam Bóg okazuje się najdłużej trwającym kłamstwem" (Nietzsche, 1907) ${ }^{35}$.

A czym skutkują takie stwierdzenia i przyjęte założenia dla zachowania czy upadku autorytetów i współczesnego kryzysu aksjologicznego? Należy zgodzić się, że obojętne nie są, ani dla rozwoju, ani dla rozwoju zrównoważonego i trwałego, rozumianego jak wyżej w tekście.

Etyka prostomyślności uniezależnia się od etyki chrześcijańskiej poprzez swój przedaksjomatyczny charakter wartości moralnych. Formalne ujęcie wartości, indywidualnie i osobiście doświadczanych jest punktem wyjścia etyki prostomyślności. Można stwierdzić, że etyka prostomyślności za swoje standarowe założenie przyjmuje wszelkie wartości, które znajduje w człowieku. Decydujące wartości świadczące o „wielkości” człowieka ukryte są w jego sferze uczuciowej - w thymos. Ta właśnie sfera stanowi o tym, jak człowiek zachowa się w sytuacji ekstremalnej, wymagającej podjęcia decyzji odnośnie wybrania określonego modelu zachowania. W związku z tym, etycznym jest nie ten, który działa dobrze, bo musi, lecz ten, kto czyni to $\mathrm{z}$ wewnętrznych pobudek. Nie ten, kto ratuje człowieka tylko, dlatego, bo inni się patrzą, ale ten, kto uczyni to, dlatego, że chce to zrobić, że życie drugiego człowieka jest dla niego bezwzględną wartością.

Kolejnym podobieństwem doktryn filozoficznych Nietzschego i Bańki jest twierdzenie, że człowiek ma pewne, ściśle określone cechy wrodzone, dziedziczne. U Nietzschego jest to instynkt moralny, a u J. Bańki prostomyślność. A w jakiej relacji wymienione instynkty pozostają do prawa naturalnego zakotwiczonego w człowieku, z którego wypływa zdolność do identyfikacji tego czym jest prawda, kłamstwo, dobro, zło, krzywda, miłość do bliźniego? Według Nietzschego każdy człowiek ma wrodzony instynkt moralny. Od najmłodszych lat zaopatrzony jest przez naturę oprócz instynktu samozachowawczego, w pewne predyspozycje do określonych postaw życiowych, modeli zachowania się w sytuacjach wyborów moralnych. Te cechy ma każdy człowiek, wyjąwszy przypadki o patologicznych przypadłościach charakterologicznych. Instynkt moralny jest swoistym mechanizmem narzucającym człowiekowi konieczność wyjścia poza pewne i określone granice ogólnie przyjętych prawideł i postaw sankcjonowanych przez daną grupę. $\mathrm{W}$ interesie pewnych grup, wysoce ważnym jest tłumienie tych instynktów, w celu narzucenia swoich modeli zachowania, zgodnie ze ściśle określonymi paradygmatami.

\footnotetext{
F. Nietzsche, Wiedza radosna („La gaya scienza”), przekł. L. Staff, Warszawa 1907, s. 298.
} 
Etyka chrześcijańska - zdaniem Nietzschego - wykazuje właśnie takie charakterystyczne tłumienie instynktu moralnego człowieka, poprzez katechizację, a w języku Nietzschego "hodowlę" młodych ludzi, i to prowadzoną bardzo konsekwentnie. J. Bańka, podobnie jak Nietzsche, twierdzi, że każdy człowiek dziedzicznie „obciążony” jest skłonnością do reakcji prostomyślnych, polegających na instynktownym działaniu dla dobra drugiego człowieka. Wolna konkurencja na wolnym rynku takich tez jednak nie potwierdza. Mechanizm powstawania tych reakcji jest podobny do tego, jaki prezentują ludzie z wrodzonym instynktem moralnym. Człowiek prostomyślny na bazie osiągniętej równowagi dynamicznej sfery phronesis i thymos, w każdej sytuacji wymagającej podjęcia życiowych decyzji, instynktownie wie, jaki model postępowania ma wybrać, aby postawa jego zasługiwała na miano zachowania moralnego. W etyce prostomyślności sumienie (resp. instynkt moralny), stanowiące jej podstawę (a zatem umocowane $\mathrm{w}$ prawie naturalnym), jest jednocześnie warunkiem koniecznym, z którego wywodzą się wartość naczelna i naczelna dyrektywa tej etyki. Opiera się ona na intuicji dobra, przez co możliwe staje się moralne poręczenie wartości i działań. „Poręczenie moralne ma, więc charakter „roszczenia moralnego” i tym się różni od prostomyślności, która ma charakter imperatywny, a więc bezroszczeniowy. Etyka prostomyślności uznaje, zatem postawę prostomyślną za ważną i godną szczególnego szacunku, a jej kształtowanie - za naczelne zadanie wychowania. Postawa prostomyślna jest, bowiem źródłem poręczenia moralnego wartości normujących życie indywidualne i społeczne. Jest ona - rzec by można - bezroszczeniowym źródłem roszczeń moralnych" (Bańka, 2004) ${ }^{36}$.

Jako kategoria uniwersalna, konstytuująca aksjologiczną wspólnotę ludzką, tzw. „lobby humanistyczne” dokonuje afirmacji wartości swoiście ludzkich. Właśnie w sumieniu - zdaniem Bańki - ma swój początek teza, iż moralistów nie różnią katalogi cnót (Bańka, 1986) ${ }^{37}$. Takie ujęcie sumienia nadaje mu charakter przedcywilizacyjny i jest rodzajem „jaźni pierwotnej” (podarowanej człowiekowi przez naturę). Jest ono źródłem normatywnego imperatywu. „Imperatyw jaźni pierwotnej wyraża zawsze konkretne, nie zaś ogólne przeświadczenie moralne i dzięki tej konkretności może być normą postępowania (conscientia moralis cocretata) (Bańka, 1988) ${ }^{38}$.

Najistotniejszy wątek i ideę stanowi w etyce dostojeństwa i etyce prostomyślności zerwanie z teorią anonimowej odpowiedzialności. Właśnie w tej ostatniej obaj filozofowie upatrują źródeł patologii społecznych, określanych mianem dekadencji kultury europejskiej. Przeciwstawiając się heglowskiej fenomenologii ducha, uspra-

\footnotetext{
36 J. BAŃKA, Słownik pojęć i tekstów filozoficznych. Przewodnik encyklopedyczny po recentywizmie, eutyfronice i etyce prostomyślności, Poznań 2004, t. II, s. 81.

37 J. BAŃKA, Etyka prostomyślności a tradycje kultury, Katowice 1986, s. 9.

38 J. BAŃKA, Świat poręczenia moralnego. Medytacje o etyce prostomyślności, Katowice 1988, s. 120.
} 
Wybrane koncepcje filozoficzne a działania medyczne dla poprawy jakości życia...

wiedliwiającej pogłębianie się anonimowej odpowiedzialności, formułują postulat odpowiedzialności osobistej. Ale taką anonimowość można zadać prawem stanowionym, orzeczeniem komisji ekspertów, referendum, regułami technologicznymi. W ramach filozofii Hegla następuje logiczne, a więc konieczne przekształcanie się ducha subiektywnego (świadomości indywidualnej) w ducha obiektywnego (świadomość grupy), aby wreszcie odnaleźć samego siebie w duchu absolutnym (świadomości ludzkości). W rezultacie tego procesu człowiek zatraca swoją niepowtarzalność i w imię bezpieczeństwa lub lenistwa konformizmu akceptuje obce dla niego wartości konstytuujące grupę, poświęcając swoją wolność, a nawet jej świadomość. Powinności moralne jawią się wtedy człowiekowi konkretnemu jako konieczne ograniczenia wolności, a dzięki „tresurze” wykształca się w nim „,instynkt stadny". Wartości funkcjonujące w grupie i dla jej przetrwania są dla jej członków dane i zadane często nawet wbrew ich woli, czy wbrew instynktowi samozachowawczemu jednostki. Może, bowiem być i tak, że w imię trwania owych wartości wszyscy jej członkowie złożą na ich ołtarzu swoje życie. Przykładów takich w historii ludzkości było wiele. Nietzscheańska krytyka moralności chrześcijańskiej, jak i krytyka skierowana „przeciw szokowi przyszłości”, mogą być interpretowane jako ostrzeżenie przed pogłębiającym się upadkiem kultury europejskiej, ale mogą też ten upadek przyspieszać. Nietrudno wyobrazić sobie konsekwencje, gdyby wszyscy wyznawcy religii chrześcijańskiej dosłownie praktykowali ascezę seksualną lub czterdziestodniowe ścisłe posty. Ale jeszcze łatwiej sobie wyobrazić konsekwencje powodowane rozwiązłością seksualną i nieograniczonym konsumpcjonizmem oraz to, czym skutkują one dla zdrowia i jakości życia. Właściwych rozwiązań należy poszukiwać w tak zwanych optymalnych przedziałach, które zapewniają ład strukturalny i umożliwiają rozwój zrównoważony i trwały.

Wydaje się, że panaceum na renesans kultury odnaleźć można w ponownym odróżnieniu moralności od prawa. Podobieństwo moralności do prawa, wyraża się w tym, że w obu przypadkach mamy do czynienia z prawodawcą, normami i sankcjami. Różnica między moralnością a prawem polega na odmiennym ich statusie, a mianowicie „immanentnym” w przypadku moralności i „transcedentalnym" w przypadku prawa. Mówiąc inaczej: prawodawca, kodeks i sankcje w przypadku prawa mają źródło poza człowiekiem konkretnym, zaś w przypadku moralności źródłem tym jest jego indywidualne sumienie. Nietzsche i Bańka, odrzucając intelektualizm etyczny Sokratesa, w swoisty sposób powracają do jego koncepcji daimoniona. Ów daimonion zawiera w sobie trzy składowe, sprawiając, iż człowiek jest, lub nie jest istotą moralną. Jest on wolny, ale nie oznacza to, że nie ma „arche” określającej jego wolność, która nie może być pojmowana jako samowola. Poznanie samego siebie odkrywa granice wolności człowieka. Akceptacja wewnętrznych ograniczeń pozwala nazwać go człowiekiem cnotliwym (Sokrates), spolegliwym (T. Kotarbiński), dostojnym (F. Nietzsche), czy wreszcie prostomyślnym (J. Bańka). 
Filozofem, według Nietschego - w podobnym duchu wypowiada się Bańka - nie jest ten, kto studiuje historię filozofii, czyli ten, kto kreuje tylko nowe interpretacje, filozofując o filozofii. Filozofem jest ten, kto powraca do jej źródeł, czyli do umiłowania mądrości, czyniącej człowieka istotą szczęśliwą, która potrafi, cieszyć się życiem i wszelkimi jego przejawami. Z tej perspektywy, zdolność filozofowania nie wymaga udokumentowania dyplomem uniwersyteckim, gdyż jest postawą, jaką człowiek potrafi zająć wobec życia. Ale czy możliwe jest umiłowanie mądrości z pominięciem aksjologii i prawa naturalnego?

Mając świadomość wartości życia oraz poznając jego istotę, którą jest stawanie się, jako aktualizowanie w teraźniejszości, człowiek uprzytamnia sobie, że jest wolny. Wolny od tradycyjnych sposobów życia, praw regulujących stosunki międzyludzkie, człowiek konkretny kierując się instynktem moralnym (sumieniem) kreuje wartości nastawione na odczuwanie pełni życia. Z tego właśnie powodu jego działanie nie polega na niszczeniu tradycyjnych wartości, którego celem jest nihilizm i amoralizm. Niszczenie odbywa się w imię poszukiwania takich wartości, które czynią człowieka szczęśliwym. A jak szczęście konkretnego człowieka przekłada się na szczęście innych ludzi, na jakość życia wszystkich i na poprawnie zdefiniowany rozwój?

Takie właśnie wartości stanowią podstawę dla bezustannie podejmowanych poszukiwań ciągle nowych sposobów bycia człowieka w świecie. Ponieważ nie ma jednego uniwersalnego sposobu życia, każdy indywidualnie musi zaczynać poszukiwania na nowo i na własna odpowiedzialność. Osobista odpowiedzialność nadająca człowiekowi dostojeństwa i godności napawa go dumą z tego, że jest istotą moralną nawet za cenę niebezpieczeństwa i samotności. Zwracając człowiekowi konkretnemu wolność, Nietzsche i Bańka uprzytamnia mu, że to on i tylko on jest odpowiedzialny za to, kim siebie uczyni, kreując wartości kształtujące sposoby życia, w imię wartości najwyższej, którą jest samo życie. W ten sposób byt skończony, jakim jest człowiek, zajmuje miejsce bytu nieskończonego, który rzekomo umarł. Jeśli jednak konkretny człowiek - każdy z osobna - sam kształtuje sposoby życia, to kto decyduje o rozwoju całości w wymiarze ekonomicznym, ludzkim i przyrodniczym, czyli o rozwoju zrównoważonym i trwałym?

$\mathrm{Na}$ czym polega wartość obu propozycji? Szczególnie pytanie to nabiera barw, kiedy spojrzy się na sytuację człowieka w dobie przemian, jakich był i jest - on udziałowcem od czasu ukazania sie „Tako rzecze Zaratustra” do momentu opublikowania „Rapu metafizycznego”. Ocena rozwoju kulturowego i cywilizacyjnego jednocześnie potwierdza zapowiedzi Nietzschego, a jednocześnie można mówić o swoistym constans pozytywów, jak i negatywów. Niewątpliwie główną ich zaletą jest uwrażliwienie człowieka na zagadnienia aksjologiczne, w tym zwłaszcza na kwestię indywidualnej odpowiedzialności. I nie chodzi tu o odpowiedzialność w „zaświatach”, ale tu i teraz, w określonej sytuacji konkretnego człowieka, tak za kreowanie własnego losu, jak i warunków życia innych 
Wybrane koncepcje filozoficzne a działania medyczne dla poprawy jakości życia...

ludzi, a i innych stworzeń. Każdy konkretny człowiek musi, powinien i w istocie odpowiada, za to, czy potrafi zająć postawę człowieka dostojnego, „spolegliwego opiekuna” zwróconego prostomyślnością do „człowieka prostomyślnego”.

Kolejną, a może wręcz najistotniejszą cechą charakterystyczna obu koncepcji etycznych jest powrót do źródła (arche) postaw moralnych, a mianowicie, do „bezinteresownej uczciwości”, nie opierającej się na autorytecie, lecz na osobistej odpowiedzialności, która konstytuuje „materię” instynktu moralnego u Nietschego i etyki prostomyślności Bańki. Wyrażam przekonanie, że współczesny kryzys aksjologiczny jest wynikiem upadku autorytetów, ale jest też odwrotnie: niszczenie autorytetów wynika z relatywizmu i anarchizmu postmodernistycznego. Zależność bowiem jest wzajemna. Zwrócił na nią uwagę hiszpański profesor J. Ortega Y Gasset w książce wydanej w 1931 roku, gdzie pokazał, że integralne kształtowanie świadomości, oparte na aksjologii, zastąpione zostało przez kształcenie sektorowe, oparte na paradygmatach (Ortega, 2002) ${ }^{39}$ co skutkuje kreowaniem człowieka masowego i negacją autorytetów.

Wracając do naszych rozważań, postmodernizm budzi nas - nawet wbrew intencjom jego przedstawicieli - ze „snu zakłamania”, „łżebycia”, instytucjonalizacji, czy penalizacji moralności. Łatwo, bowiem jest być uczciwym bezinteresownie, trudniej zaś, kiedy jej zasady są „obserwowane” przez „daimoniona” wobec człowieka transcendentalnego. Może czas na autentyczna - bezinteresowna - uczciwość, tak w zakresie etyki w ogóle, jak i deontologii - w tym także, a może przede wszystkim - etyki lekarskiej. Chciałbym podkreślić, ze „Doktorem X.” może być każdy, ale bycie „Doktorem Judymem” to powód do dumy bycia człowiekiem i to w każdej sytuacji. Nagrodą jest - może i naiwne, ale i zobowiązujące - bycie uczciwym człowiekiem, który traktuje swój zawód jako powołanie i misję. W ten sposób lekarz może wpisać swoją działalność w poprawę jakości życia innych ludzi i w rozwój zrównoważony i trwały. Jakkolwiek uwarunkowania instytucjonalne mogą jego postawę korygować i weryfikować (np. przez wysokie podatki).

\section{Podsumowanie}

Rozważania nad kategorią „rozwój”, zasadą zrównoważonego rozwoju (art. 5 Konstytucji RP) i nad koncepcją zrównoważonego rozwoju (art. 20 konstytucji $\mathrm{RP}$, który definiuje koncepcję rozwoju - społeczna gospodarka rynkowa) znajdują umocowanie w godności osoby ludzkiej, aksjologii i depozycie niezrelatywizowanych wartości, które w procesie rozwoju pełnią funkcje kryterialne (F. Piontek $2006)^{40}$. Zapisała to w graficznym modelu rozwoju (B. Piontek, 2000, 2002, 2004,

\footnotetext{
39 J. Ortega y Gasset., Bunt mas, Wydawnictwo Muza S. A., 2002, s. 60 i 117 - 124.

40 A. PAwŁowski, Wielowymiarowość rozwoju zrównoważonego, Problemy Ekorozwoju, vol. 1, No 1,2006 , s. 23-32.
} 
2007) ${ }^{41}$. Funkcja tych kryteriów (aksjologia, prawo naturalne, godność człowieka) w prezentowanym modelu rozwoju jest korygująca i weryfikująca, z punktu widzenia kształtowania i doskonalenia ładu strukturalnego, godności człowieka i poprawy jakości jego życia.

Wartości takie jak: moralność, uczciwość, dostojność i prostomyślność człowieka mogą i powinny przekładać się na poprawę jakości życia, a w dalszym etapie na rozwój, który zadany został człowiekowi prawem natury. Etyka bezinteresownej uczciwości i etyka prostomyślności w obszarze medycyny wpisuję się w ten model rozwoju ponieważ zachodzi relacja człowiek - człowiek.

Natomiast w sytuacjach kiedy relacja: człowiek - człowiek jest łamana przez kapitał ekonomiczny, przez technologie, wtedy bezinteresowna uczciwość i prostolinijność konkretnego człowieka przestają być skuteczne w urzeczywistnianiu rozwoju i trwałej poprawy jakości życia. Kapitał ludzki, jego wartość w postaci właściwej postawy etyczno-moralnej, a nie wyłącznie nakazy, zakazy prawne i technologie pełnią wiodącą rolę w urzeczywistnianiu właściwie rozumianego rozwoju (Pawłowski 2009) ${ }^{42}$. Bazowanie wyłącznie na kapitale intelektualnym społeczeństwa i nowoczesnych technologiach, nie jest wystarczające i skuteczne dla tworzenia właściwych relacji w zakresie kapitału ludzkiego, wzrostu gospodarczego, ładu społecznego, co ma bezpośredni wpływ na urzeczywistniony rozwój. Właściwe połączenie kapitału intelektualnego, technologicznego z etyczno-moralnym daje silne podstawy do podniesienia jakości życia i właściwego kształtowania rozwoju społeczeństwa.

\footnotetext{
41 B. Piontek, Koncepcja rozwoju zrównoważonego i trwałego Polski, PWN, Warszawa 2002, s.7485; B. Piontek, Współczesne uwarunkowania rozwoju społeczno - gospodarczego, ATH, Bielsko Biała 2000; F. Piontek, A. J. NowAK, Osobowy aspekt wartości w procesie rozwoju, WSEiA, Bytom 2004, także F. PIOnTek, Podstawy teorii rozwoju (w:) ROZWÓJ: godność człowieka - gospodarowanie - poszanowanie przyrody. Księga Pamiątkowa prof. zw. dr hab. Franciszka Piontka, Red. B. Piontek, W. Piontek, PWE, Warszawa 2007, s. 59-91

42 PawŁowski A., Rewolucja rozwoju zrównoważonego, Problemy Ekorozwoju, vol. 4, No 1, 2009, 65-76.
} 
Wybrane koncepcje filozoficzne a działania medyczne dla poprawy jakości życia...

\section{SUMMARY}

Constitutional features of ethics in general, in both the descriptive and normative meanings, or deontology, are certainly freedom of choice strictly related to responsibility, the axiological system, etc. I advance a thesis that ethical eidetic must concentrate on the issue of human honesty. The analyzed ethical proposals, those of Friedrich Nietzsche and Józef Bańka, place the importance of philosophical reflection and speculation on this issue.

The modern axiological crisis is a result of the collapse of authorities and not, inversely, that the destruction came from relativism and post-modernistic anarchism. It is easy to be disinterestedly honest; it is more difficult when its rules are being "observed" by a "daimonion", which is transcendental to a human. Perhaps it is time for authentic, disinterested honesty, both in the rules of ethics and in deontology, and also, or perhaps mainly, in medical ethics, which has essential significance for the improvement of life quality, constituting an essential criterion in the process of realising development. But if the honesty does, during the building of the technical civilization?.

Key words: ethics, Friedrich Nietzsche, Josef Bańka, human honesty, quality of life, development, sustainable and lasting development: 